\title{
Ribonucleic Acid
}

National Cancer Institute

\section{Source}

National Cancer Institute. Ribonucleic Acid. NCI Thesaurus. Code C812.

Single-stranded long chain of nucleotides containing ribose. It is the end product of DNA transcription by the enzyme RNA polymerase. It is essential in protein synthesis. 